University of Chicago Law School

Chicago Unbound

\title{
The Problematic Concept of Possession in the DCFR: Lessons from Law and Economics of Possession
}

Yun-oschien Chang

Follow this and additional works at: https://chicagounbound.uchicago.edu/public_law_and_legal_theory

Part of the Law Commons

Chicago Unbound includes both works in progress and final versions of articles. Please be aware that a more recent version of this article may be available on Chicago Unbound, SSRN or elsewhere.

\section{Recommended Citation}

Yun-1Echien Chang, "The Problematic Concept of Possession in the DCFR: Lessons from Law and Economics of Possession," University of Chicago Public Law \& Legal Theory Paper Series, No. 567 (2016).

This Working Paper is brought to you for free and open access by the Working Papers at Chicago Unbound. It has been accepted for inclusion in Public Law and Legal Theory Working Papers by an authorized administrator of Chicago Unbound. For more information, please contact unbound@law.uchicago.edu. 


\title{
CHICAGO
}

COASE-SANDOR INSTITUTE FOR LAW AND ECONOMICS WORKING PAPER NO. 750

PUblic LAW AND LEGAL THEORY WORKING PAPER NO. 567

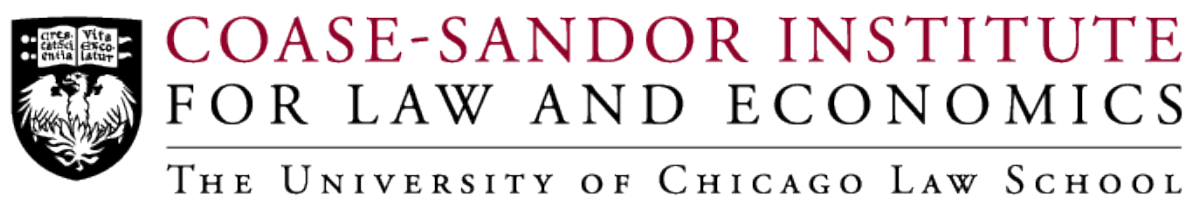

THE PROBLEMATIC CONCEPT OF POSSESSION IN THE DCFR: LESSONS FROM LAW AND ECONOMICS OF POSSESSION

\author{
Yun-chien Chang \\ THE LAW SCHOOL \\ THE UNIVERSITY OF CHICAGO
}

February 2016 
The Problematic Concept of Possession in the DCFR:

Lessons from Law and Economics of Possession

\author{
Yun-chien Chang*
}

\begin{abstract}
$\underline{\text { Abstract }}$
The concept of possession in law has been a complicated one for hundreds of years, and many civil codes are complex in their own idiosyncratic ways. (Draft) Common Framework of Reference is no exception, and it even contains arguably one of the most complicated possession stipulations ever. This article first summarizes the gist of each chapter in a new book the author edited, Law and Economics of Possession. Then, this article applies the economy of concept theory developed by Henry Smith to the concept of possession and critiques the DCFR for manipulating the notion of physical control. To demonstrate the downside of cerebral concept, this article provides several examples where the DCFR contradicts itself. As an alternative, this article contends that possession defined as physical control and without any exception is both simple and useful. No doctrine needs to be changed substantively. The doctrines are only constructed more clearly. In addition, the DCFR raises the question of whether possession is a fact or a right, but fails to provide a sound explanation. This article argues that possession is both a fact and a subsidiary right, depending on which dimension of possession is discussed.
\end{abstract}

\title{
Keywords
}

Right to possess, physical control, owner-possessor, possessor-agent, limitedright-possessor, indirect possession, Draft Common Frame of Reference (the DCFR)

\footnotetext{
* Associate Research Professor \& Director of Center for Empirical Legal Studies, Institutum Iurisprudentiae, Academia Sinica, Taiwan. J.S.D., New York University School of Law. Email: kleiber@sinica.edu.tw. Part II of this article is adapted from the Introduction in Law and Economics of Possession. I thank Prof. Sjef van Erp, Editor-in-Chief of European Journal of Property Law, for the invite to write this article. Marija Bartl, Selma de Groot, Karoline Haug, Martijn Hesselink, Aart Jonker, Candida Leona, Joasia Luzac, Arthur Salomons, Rolef de Weijs, and other participants in the private law workshop at the University of Amsterdam provide helpful comments. Alice Kuo and Hilary Tsai provided research assistance. Ministry of Science and Technology, Taiwan (research grant number: 101-2410-H-001-020-MY3) provides financial support for this article.
} 


\section{Table of Contents}

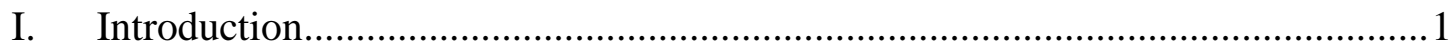

II. Law and Economics of Possession in a Nutshell...................................................

III. A Critique of the Possession Concept in the DCFR ...........................................

A. The Mysterious Physical Control...............................................................

B. Concrete Examples where the DCFR Is Confusing.................................... 11

C. My Solution: Possession as Physical Control (Period).................................13

D. Is Possession a Fact or a Right? ............................................................... 16

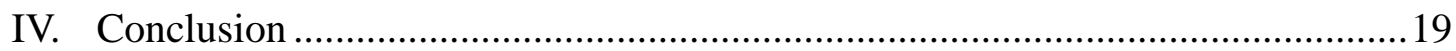




\section{INTRODUCTION}

My edited book, Law and Economics of Possession, was published by Cambridge University Press in May 2015. ${ }^{1}$ Contributors to this volume include Benito Arruñada, Abraham Bell, Richard Epstein, Daniel B. Kelly, Daniel Klerman, James Krier, Daphna Lewinsohn-Zamir, Thomas Merrill, Shitong Qiao, Carol Rose, Christopher Serkin, Henry Smith, and myself. Each book chapter employs lawand-economics to analyze general or concrete possession issues in property law. To give readers of this journal a quick overview of the book, at the suggestion of Editor-in-Chief Prof. Sjef van Erp, I summarize the gist of each chapter in Part II of this article. To show the policy implication of property law and economics theory for European private law, Part III applies the "economy of concept theory" relied on in my book chapter to critique the possession-related stipulations in Draft Common Frame of Reference (the DCFR).

Economic analysis of law, the research approach used in the aforementioned edited volume, has been the dominant methodology used in the past half-century in the U.S. The success of law and economics in the U.S. can partly be attributed to the federal system, where each state has its own common law and state regulations. Diversity is the best soil for law and economics. When there is only one court, one code, or one set of rules, jurists would be prone to take the existing doctrines as granted, and black-letter law studies would have the upper hand. Nevertheless, when jurisdictions in an internal market compete with each other, or when scholars compare the same doctrine across near-by jurisdictions, differences loom large. A natural question arises: which variant of the doctrine is the best? Against this backdrop, economic analysis of law offers economics efficiency as the measuring stick of desirability, and this approach has led to fruitful results. ${ }^{2}$

Law and economics has been thriving in Europe in the past several decades

\footnotetext{
1 Y-c Chang (ed), Law and Economics of Possession (Cambridge University Press, Cambridge 2015).

2 For comparative law and economics researches, see, e.g., Y-c Chang, 'Property Law with Chinese Characteristics: An Economic and Comparative Analysis' (2012) 1 Brigham-Kanner Property Rights Conference Journal 345; Y-c Chang, 'Access to Landlocked Land: A Case for a Hybrid of Property and Liability Rules' (2013) working paper ; Y-c Chang, 'An Economic and Comparative Analysis of Specificatio (the Accession Doctrine)' (2014) 39 European Journal of Law and Economics 225; Y-c Chang and LA Fennell, 'Partition and Revelation' (2014) 81 The University of Chicago Law Review 27; U Mattei, Basic Principles of Property Law: A Comparative Legal and Economic Introduction (Greenwood Press, Westport, Conn. 2000); H Hansmann and U Mattei, 'The Function of Trust Law: A Comparative Legal and Economic Analysis' (1998) 73 New York University Law Review 434.
} 
as well. ${ }^{3}$ The European Association of Law and Economics is almost as old as I am, and the 32nd annual conference is held in 2015. Doctrinal study of law (Rechtsdogmatik) has been, and still is, the mainstream in Europe, as most legal scholars traditionally focus on the domestic laws in one EU member state. Like the U.S., Europe contains dozens of jurisdictions and in many ways the differences in legal systems across jurisdictions are greater in Europe. With the progress of harmonization of law in Europe and projects like the DCFR, it should not be surprising that legal scholars nowadays are searching for analytical tools that could help answer the question of which variant of a doctrine is better to serve as the model for the whole of Europe. ${ }^{4}$ Economic analysis of law is not the only approach that could supply a plausible answer, but the policy recommendation is often fresh, interesting, and illuminating - at least from my biased point of view. In searching for a common framework toward European private law, economic analysis of law will, I hope, prove instrumental in evaluating the pros and cons of property regimes in various European countries, and contribute to pinpointing the most desirable property doctrines for Europe.

To concretely demonstrate the insights of law and economics, in Part III, I critically examine the possession-related rules in the DCFR. Arthur Salomons has pointed out two prototypical approaches in drafting the CFR: the best-solution approach and the common-core approach. ${ }^{5}$ Salomons also observed that as time goes by, the drafters of Volume VIII of the DCFR drifted away from the commoncore approach. Economic analysis of law is best characterized as a best-solution approach. My argument that possession should be defined as simply physical control without any exception exemplifies such an approach. To my knowledge, no European jurisdiction has adopted such a revolutionarily simple idea, thus my design is neither common nor core, but I shall argue that it is the best solution.

\footnotetext{
3 Compare Arthur Salomons, who has lamented that law and economics has "hardly made any headway in Europe.” AF Salomons, 'On the Economics of Good Faith Acquisition Protection in the DCFR' in A Somma (ed) The Politics of the Draft Common Frame of Reference (Wolters Kluwer, New York, NY 2009) 207.

${ }^{4}$ For the concept of possession in the first legal model for Europe (that is, the Roman law), see RA Epstein, 'Possession and Licenses: the FCC, Weak Spectrum Rights, and the LightSquared Debacle' in Y-c Chang (ed) Law and Economics of Possession (Cambridge University Press, Cambridge 2015) 237-46; E Descheemaeker, 'The Consequences of Possession' in E Descheemaeker (ed) The Consequences of Possession (Edinburgh University Press, Edinburgh 2014) 9-11.

5 AF Salomons, 'The Purpose and Coherence of the Rules on Good Faith Acquisition and Acquisitive Prescription in the Draft Common Frame of Reference: A Tale of Two Gatekeepers' (2013) 21 European Review of Private Law 843, 861.
} 


\section{LAW AND ECONOMICS OF POSSESSION IN A NUTSHELL}

Law and Economics of Possession begins with Thomas Merrill's “Ownership and Possession.” Merrill analyzes the concepts and relations of possession and ownership from the perspective of information costs. Possession imposes low information costs in the world of strangers, whereas ownership, which is harder to prove, requires more information costs in order to conduct impersonal exchange. In the modern world where recording or registration of titles is cheaply available, the reason to continue protecting possession independently of ownership, is that possession can be determined by observing the relationship between natural persons and tangible objects in a physical world-usually simple and easy. This allows ordinary people to conduct their daily business without expending high information costs. Protecting possession legally can also empower social norm to sanction possession violators and relieve people's burdens of resorting to recording of titles from time to time or to keeping documentary proofs of ownership such as receipts for long periods of time.

Carol Rose, in Chapter 2, analyzes the proverb "possession is nine-tenths of the law," inquiring what the other point of the law is (one regular candidate being provenance) and whether this proverb is an accurate description of the world. Rose argues that possession is not just about physical control, or the right to exclude, but about acting like an owner. Generally, using makes one act like an owner. She finds support for such a claim from the case law of first possession and adverse possession. Rose also emphasizes the importance of community support and recognition of possession. Her takeaway point is that when the law is weak, possession is nine-tenths of the law. By contrast, when the law is settled, the law is nine-tenths of possession.

Henry Smith offers a modular theory of possession. Smith emphasizes salience in identifying and delineating possession. For Smith, along the same lines with longtime coauthor Merrill, possession is very much based on social norms and is the default in property law because it is low-cost and intuitive for the public. More formalized legal tools, such as ownership, will be used only when stakes become high. Note that possession itself is a formalized version of the possessory custom, the ultimate default regime for assigning things to persons. Possession thus exhibits what Smith calls the "elsewhere pattern," meaning that "possession is defined by not being anything else." More specifically, possession is the most basic rule in many scenarios, and possession applies when nothing else does. Smith also observes that although civil law 
treats property as the law of things, common law eschews this notion. However, the function that the concept of things served in civil law is captured by the concept of possession in the common law. Possession (with close ties to customs and informal norms) and accession work in tandem to determine what a thing is (and, relatedly, what are only elements of a thing but not a thing itself). Thinghood, or the demarcation of things, very much depends on general, everyday ontology, echoing Merrill's point.

My own chapter, "The Economy of Concept and Possession," draws on Henry Smith's economy of concept theory ${ }^{6}$ and argues that a simpler concept of possession (with actual/physical control as the necessary and sufficient condition) economizes on information costs and makes the possession law much more comprehensible. The confusion in the civil codes and the scholarly literature arises from conflation of three different concepts: possession as a fact; possession as a subsidiary right that is one stick in the ownership bundle; and possession as a basis for acquiring and relinquishing titles, as in adverse possession, first possession, and abandonment. Actual/physical control is the least common denominator in all possession-related issues; thus, possession qua actual/physical control is a fact. The subsidiary possessory right is implied in the property structure, but it is never spelled out. It can be transferred from owners to, for example, holders of usufruct. Finally, intents only matter when possessors gain or lose titles, and the required intents differ across contexts; thus, a specific intent should not be embedded in the baseline definition of possession, but left to specific doctrines. As elaborated below, the baseline definition of possession is useful in many parts of a civil code, such as self-help, revindication, and goodfaith purchase. As the DCFR fails to stick to the baseline definition of possession, it has to be further complicated the relevant doctrines to restore order-which could have been easily achieved by the simple definition of possession as physical control.

Lewinsohn-Zamir, in Chapter 5, draws on the findings of behavioral-lawand-economists. She takes these researchers to task for failing to distinguish possession from ownership (not to mention lawful from unlawful possession),

\footnotetext{
${ }^{6}$ HE Smith, 'On the Economy of Concepts in Property' (2012) 160 University of Pennsylvania Law Review 2097. In short, a shorter description of a fact or a concept with the same generality better economizes on information costs. For most people, 2015 A.D., as compared to 2566 years since Confucius was born, better economizes information costs, even though both refer to the same year. A more economic conceptual system helps to reduce errors in the legal systems, as it is easier to understand and implement. As evidenced below, the drafters of the DCFR chose a fairly complex conceptual system of possession, and as a result made many conflicting statements. If drafters fail to firmly grasp their own conceptual system, later users are hopeless.
} 
but notes that the few studies that attend to the difference suggest that possession itself looms large in creating the "endowment effect."

Like Lewinsohn-Zamir, in Chapter 6, James Krier and Christopher Serkin draw on the psychological literature, most notably the System 1 versus System 2 theory popularized by Daniel Kahnemann. Krier and Serkin point out that the scholarship of Thomas Merrill and Henry Smith focuses on information costs and the right to exclude; thus, their views can be characterized as emphasizing the quick but error-prone role of System 1. Other scholars, by contrast, stress the importance of making complex arrangements in property law to promote normative goals, such as human flourishing. It takes the sharp yet energyconsuming System 2 to perform this trick. As their chapter title suggests, Krier and Serkin focus on possession as heuristics, echoing Merrill, in Chapter 1. They powerfully apply their possession heuristics thesis to criticize theoretical literature and court decisions in the realm of relativity of title, first possession (capture) of wild and domesticated animals and natural resources, finders of lost versus mislaid movables, shared possession in concurrent ownership, and adverse possession.

Daniel Kelly, in Chapter 7, critically reviews the scant literature on whether an owner's private incentive to divide possessory rights will exceed the socially optimal level. Kelly contends that most costs and benefits of such division are internalized, and thus fragmentation is unlikely, particularly for tangible objects. Kelly also draws on the psychology literature, observing that individuals are inclined to hold full rights (rather than partial rights) in a resource. Contributing to the debate on the efficiency of the numerus clausus principle, Kelly points out that property forms, as compared to contracts, better deter strategic behaviors, implying that in areas where owners' incentives to divide possessory rights are suboptimal. Adding new property forms could improve efficiency, as new property forms facilitate division.

Focusing on information costs, Benito Arruñada, in Chapter 8, examines how possession gives notice to facilitate impersonal exchange. Drawing examples from the Roman law and medieval English law to modern German and US law, Arruñada demonstrates that "exercise" of possession is effective as a titling mechanism when it is observable by third parties and "delivery" of possession (for example, livery of seisin) is public knowledge. In addition, as possession is only effective to inform one single in rem right, relying on possession for titling requires that all other rights be either reduced to in personam status or be burdened by the possessory in rem right. Arruñada also 
analyzes documentary possession (such as possession of negotiable instruments), and argues that documentary possession is effective as a titling mechanism only in the absence of multiple in rem rights.

Richard Epstein, in Chapter 9, focuses on spectrum rights, particularly the so-called "LightSquared Debacle." He begins with a restatement of possession versus ownership law in Roman and English law, tracing the concept of possession. After a detailed description of the LightSquared controversy, Epstein points out that the weak property rights given to spectrum licensees are due to the FCC's ill-advised regulatory policy. He argues that the same system of possession and property rights used in the common law is also applicable to spectrum, which more resembles trade names and trademarks than copyrights and patents. The nuisance law, in particular, can be carried over to protect holders of broadband interests.

Daniel Klerman, in Chapter 10, analyzes choice of law and jurisdiction issues in property, with appropriation of water, adverse possession of stolen arts, and first possession of wild animals as the prominent examples. Klerman argues that the situs rule is mostly correct in terms of giving individuals, legislators, and judges the right incentives to behave efficiently (such as making efficient laws or making best use of the land and attendant water). In the context of adverse possession of stolen arts, however, a choice of law rule that applies the law of the last place of undisputed ownership gives the relevant parties the best incentives. Regarding jurisdictional issues, although Klerman points out that there is no clear-cut best rule in stolen arts issues, he contends that the courts of the place where the art was last undisputedly owned are good candidates.

Shitong Qiao, in Chapter 11, focuses on a unique adverse possession problem: "small property" in Shenzhen, the fourth largest city in China. In China, rural land is collectively owned, whereas urban land is state-owned. Only urban land can be commercially developed, and the only way to convert rural land to urban land is through eminent domain. The economic development in Shenzhen in the past few decades was faster than the pace of providing enough affordable housing by the government. As a result, farmers/villagers in Shenzhen started to build illegal houses and condominiums despite the legal ban. That is, they adversely possessed and developed public land. Without an adverse possession law, developers could not acquire formal title to the buildings and only had "small property" rights. With first-hand materials from his yearlong fieldwork in Shenzhen, Qiao argues that a call-option liability rule is the most efficient in 
dealing with the small-property conundrum because of information asymmetry between the government and the numerous holders of small-property rights.

In the final chapter, Abraham Bell leads us to one of the most famous possession doctrines, the first possession rule, and reexamines the normative impulse for property law's use of possession as a key to acquiring greater property rights. Bell challenges Richard Epstein's classic view in his seminal article, "Possession as the Root of Title." 7 Epstein posits that first possession is an essential rule in property law primarily because it long has been used, and it provides for rapid dissemination of private property rights. Bell argues that in some cases, property law recognizes first possession as a source of title for an entirely different reason: it is essential to recognize rights de jure that already exist de facto, lest the legal system of property lose its salience. Put differently, if the law did not recognize legal rights as a result of possession, many first possessors would find it advantageous to eschew legal rights and protect their possessory rights extra-legally. Indeed, in cases where the law denies property rights notwithstanding possession, robust extra-legal asset markets have developed, undermining the goals that led lawmakers to split property rights from possession. Examples of this phenomenon can be found, for instance, in the markets for illegal antiquities and natural resources. However, first possession is often a problematic way to allocate titles; salvage rules can often provide an alternative that both rewards de facto possession and reduces wasteful overexploitation.

\section{A CRITIQUe OF THE POSSESSION CONCEPT IN THE DCFR}

In my book chapter on economizing the concept of possession, I draw examples from national laws in Germany, France, the Netherlands, Japan, China, and Taiwan. This part applies my theory to examine the possession stipulations in Book VIII of the DCFR. My conclusion is that, the DCFR, like the national laws I examined in my book chapter, unfortunately adopts an overly complex concept of possession. Complexity leads to confusion and contradiction. ${ }^{8}$

My proposal is modest: define possession as actual/physical control—no

\footnotetext{
7 RA Epstein, 'Possession as the Root of Title' (1979) 13 Georgia Law Review 1221.

${ }^{8}$ Henry Smith would point out that when possession becomes unintuitive for the public, it hampers possession's default function in property law. HE Smith, 'The Elements of Possession' in Y-c Chang (ed) Law and Economics of Possession (Cambridge University Press, Cambridge 2015).
} 
more; no less. ${ }^{9}$ The underlying rationale, elaborated in my chapter, ${ }^{10}$ is that possession, a basic element in private law, is drawn upon in many parts of Book VIII (Comment A to VIII-1:205) ${ }^{11}$ and other private-law doctrines. Nevertheless, possession is just one concept and it can be combined with other concepts in various doctrines. ${ }^{12}$ Thus, the concept "possession" need not contain too many elements. Put differently, possession as the least common denominator is the simplest way to coordinate various possession-related doctrines in private law. Moreover, the party who has physical control is often the least cost avoider in many legal issues. Thus, it is substantively efficient to impose liability on, and award benefits to, the party with physical control. ${ }^{13}$ It is conceptually efficient to call such parties simply possessors rather than a complicated set of rules or terms to describe such parties.

A recent article by Thomas Merrill, Possession as a Natural Right, ${ }^{14}$ bolsters my argument from another angle. Merrill, using examples from traditional and digital IP rights and real property rights, contends that "property systems draw heavily upon, and derive much of their legitimacy and efficacy from, mimicking or synchronizing with possession." 15 Possession, for Merrill, has a biological foundation and thus people in all human society have what he calls "possession instinct."16 Possession, as Merrill depicts, can be effortlessly understood by ordinary people in daily context. While Merrill does not provide an intensive definition of possession (he does point out that possession is grounded in exclusion ${ }^{17}$ ), the possession concept that could work in his theory must be a simple and intuitive one. There could be a few ways of defining possession along this line, and suffice for me to point out here that my definition of possession as physical control is one of those fitting definitions. People embedded in their own

\footnotetext{
9 Cf. CM Rose, 'The Law Is Nine-tenths of Possession: An Adage Turned on Its Head' in Y-c Chang (ed) Law and Economics of Possession (Cambridge University Press, Cambridge 2015)(possession is more about acting like an owner); D Lewinsohn-Zamir, 'What Behavioral Studies Can Teach Jurists about Possession and Vice Versa' in Y-c Chang (ed) Law and Economics of Possession (Cambridge University Press, Cambridge 2015)(expanding the extension of possession).

10 Y-c Chang, 'The Economy of Concept and Possession' in Y-c Chang (ed) Law and Economics of Possession (Cambridge University Press, Cambridge 2015) 117-124.

11 Study Group on a European Civil Code \& Research Group on the Existing EC Private law (Acquis Group), Draft Common Frame of Reference (the DCFR). Full Edition: Principles, Definitions and Model Rules on European Private Law Reference (1st edition, Seller European Law Publishers 2009) 4291.

12 Chang (n 10) 121.

13 Ibid 123-24.

14 TW Merrill, 'Possession as a Natural Right' (2015) 9 New York University Journal of Law \& Liberty 345.

15 Ibid 356.

16 Ibid.

17 Ibid 371.
} 
social norm understand physical control in its non-technical sense.

Before I elaborate on my arguments, let me be clear that I do not mean to disparage the commendable drafters of the DCFR. The possession concept in the DCFR is largely based on the German $B G B$ paradigm, and even if drafters of the DCFR had chosen the French $C C$ paradigm that distinguishes between detention and possession, it is not necessarily an improvement in conceptual clarity. Most codified private laws in Europe (and East Asia) have been trapped in the traditional conceptual system. The DCFR is no exception. My goal is to advocate a clearer possession concept with a slim hope to influence the final political CFR and/or European Civil Code. Below I demonstrate how an overly complicated conceptual system could contradict itself and creates problem for understanding.

Section A questions the exact meaning of physical control and points out that its definition changes throughout Volume VIII. Section B provides several concrete examples of how the possession concept creates confusion. Section $C$ advocates an alternative way to conceptualize possession. Section D contends that possession is both a fact and a subsidiary right, and distinguishes in rem and in personam right to possess in the DCFR.

\section{A. The Mysterious Physical Control}

the DCFR VIII-1:205(1) defines possession as "having direct physical control or indirect physical control over the goods." The meaning of physical control, however, is nowhere to be found in the articles and comments of the DCFR. Indeed, this ambiguity proves to be critical, as it leaves room for the DCFR to manipulate the concept of possession.

The DCFR sets the stage of confusion by coining various new terms, such as owner-possessor (OP), limited-right-possessor (LRP), and possessor-agent (PA). It seems to me, an Asian civil property law scholar, that this is a wild term parade without a clue of what the celebration is for. The DCFR Comments do not elaborate why these new concepts are necessary and do not persuasively explain their conceptual or functional advantage over alternative possession concepts. Before elaborating on my proposal, I demonstrate the conceptual problem in the DCFR.

VIII-1:205 equates possession as "having direct physical control or indirect physical control over the goods" without requiring possessors to have any intention to possess (animus). Hence, it appears that possessors are whoever has 
physical control. ${ }^{18}$ VIII-1:206 defines that OPs shall have the intention of controlling as, or as if, an owner. According to VIII-1:207, LRPs must have one of two required intentions. At this point, the conceptual system is clear: possessors with certain intentions would be labeled as OPs or LRPs, whereas possessors without those intentions would be bare-bone possessors. Finally, VIII-1:208 defines possessor-agents (PA) as exercising possession without the aforementioned intentions. Now it starts to be confusing for a novice: Isn't PA then synonymous with possessors? Or are PAs one type of possessors? Worse yet, the DCFR Comment makes it clear that PAs are not possessors. The concepts do not add up for readers of the outline edition of the DCFR. One has to immerse oneself in the thousands of pages of the DCFR Comments and Notes in the full edition of the DCFR and parses through the text to start to have a better idea.

The devil is in the details. As emphasized in Comment D to VIII-1:205, 19 a verb makes all the difference. PAs are not possessors because they merely exercise physical control but do not have physical control. VIII-1:205(1) has carefully defined possession as having physical control, while VIII-1:205(2)-(3) and the following three articles choose exercising physical control as the critical element. But, apart from the slight semantic difference, what is the real difference? the DCFR does not address this issue.

To find out the answer, we have to return to the initial question of what physical control is, which is a difficult one. Leave aside what "having physical control" means for a moment, and focus on exercising physical control. VIII1:205(2) characterizes a person who exercises physical control personally as a direct possessor. This is easy to understand. One may quarrel over the nuance differences between any proposed definitions for exercising physical control in this scenario and may debate in marginal cases whether the person in question exercises physical control. But most pragmatic jurists should be able to reach a consensus in most cases. For instance, I locked my car and have the key in my backpack. I thus physically control the car and the key in person. ${ }^{20}$ But then VIII1:205(2) and VIII-1:207 allow me to use PAs to exercise my control. For example, I drive to a fancy new restaurant and hand my car key over to a valet who I have

\footnotetext{
18 Akkermans also questions why the DCFR does not include intention in the definition of possession. B Akkermans, 'The role of the (D) CFR in the making of European property law' in V Sagaert, M Storme and E Terryn (eds), The Draft Common Frame of Reference (DCFR): A National and Comparative Perspective (Intersentia, Cambridge 2012) 281.

19 the DCFR Full Edition 20094295.

${ }^{20}$ Some would question that since I am away from the car, how can I in the literal sense physically control the car? In my chapter, I solve this question by delineating someone's possession as continuous until someone else has taken up stronger physical control. Chang (n 10) 117.
} 
never met. Now, at my dining table, I have no idea where the valet, my key, and my car are. But I can rest assured that the DCFR recognizes me as a direct possessor because I have physical control. But isn't the definition of (exercising) direct physical control just expanded to possession through an agent?

Moreover, VIII-1:205(3) makes things more complicated by explicitly allowing physical control to be indirect. I actually rented the car from Avis a few days ago at a 300-mile-away airport. I am relieved to know that the DCFR dubs me as a direct possessor, but I am also amused to know that Avis the mother company or the airport branch is considered an indirect possessor of the car. I do plan to return the car, but how in the world does Avis physically control the car, in the literal sense of the term, albeit only indirectly? ${ }^{21}$ Under ordinary English grammar, indirect physical control is still physical control, so the intension and extension of physical control have to be wide enough to encompass both indirect and direct physical control. That will have to be very wide. Also, what does the word physical mean? My Oxford English dictionary gives several explanations, the most relevant of which are "connected with a person's body rather than their mind" and "connected with things that actually exist or are present and can be seen, felt, etc. rather than things that only exist in a person's mind." To me, in many instances, indirect physical control and direct physical control through an agent are anything but physical. Indirect physical control is an oxymoron. ${ }^{22}$

All in all, the meaning of physical control varies depending on whether the possession is in the hand of an indirect possessor, a direct possessor personally exercising physical control, and a direct possessor who employs an agent. In the next section, I provide more examples of the deficiency of the DCFR.

\section{B. Concrete Examples where the DCFR Is Confusing}

While lawyers might be proud of their prowess with jargon and their capabilities of navigating conceptual mazes, an overly complex conceptual system would confuse even the drafters of the DCFR, leading to contradictory stipulations and statements. ${ }^{23}$ Here are a few examples:

\footnotetext{
21 Some would contend that Avis is still the possessor because I the tenant merely hold detention. My response is that the very distinction of possession and detention marks the beginning of complicating the concept of possession. We need to step back to reconsider why the concept of detention is needed in the first place. Under my theory, there is no need to make such a distinction. The concept of detention is dispensable.

${ }^{22}$ For my critique of indirect possession as possession, see Chang (n 10) 118-120.

23 As Krier and Serkin note, it takes our System 2 to design a complicated legal mechanism. JE Krier and C Serkin, 'The Possession Heuristic' in Y-c Chang (ed) Law and Economics of Possession
} 
First, is a PA a possessor or not?24 As said above, the DCFR Comment explicitly states that "the movable is not in the possession of the PA in the legal sense," 25 and the DCFR Comment states that "the PA will have direct physical control of the movable (which is actually considered as the OP's or LRP's direct possession)" 26 But this "consideration" 27 or "attribut[ion]" 28 is nowhere to be found in the articles themselves. Readers of the DCFR Outline would reason that VIII-1:208(1)(a) defines a PA as exercising direct physical control and VIII1:205(2) recognizes a person who exercise direct physical control personally as a direct possessor-PAs, therefore, shall be possessors. Granted, PAs lack intention to possess, but according to the articles themselves, lack of intention only deprives a PA of OP or LRP status, but not possessor status. Readers of the DCFR Outline could correctly understand the original intents of the DCFR drafters only if they suspect that "having" and "exercising" physical control have very different meanings. Indeed, the DCFR Comment, due to perhaps an oversight, recognizes that "PA is in possession of the movables," 29 and the DCFR Comment admits that "the actual physical control is with [PA]." 30 In short, if the DCFR is a civil code and only articles themselves have legal forces, a PA is a possessor. The opposite conclusion would require revision of the articles.

Second, not recognizing PAs as possessors impose adverse effects on other doctrines. Regarding self-help, the DCFR intends to enable PAs to exert self-help, but has stated in Comments that PAs are not possessors. To make it work, VIII6:202 allows "a third person" to exert "self-help." It is again perplexing, at least from a linguistic standpoint. If self means the first person, why can a third person resort to it as well? This design is mainly to award PA the power of self-help, because it is "an efficient means to protect the legitimate interests...." 31 Again we see why PA should be considered a full-blown possessor to begin with. Also confusingly, the DCFR Comment $\mathrm{C}$ mentions in passing that "third parties [other than PAs] wishing to help someone defend property or possession" can also exert self-help. ${ }^{32}$ This deserves more explanations.

(Cambridge University Press, Cambridge 2015). Our System 2 is, however, limited, so drafters are prone to make errors when their brains are overloaded by the complexity. For System 1 vs. System in general, see D Kahneman, Thinking, Fast and Slow (Farrar, Straus and Giroux, New York, NY 2011).

${ }^{24}$ For my critique of PAs (agents in possession) as non-possessors, see Chang (n 10) 120-123.

25 the DCFR Full Edition 20094295.

26 the DCFR Full Edition 20094371.

27 the DCFR Full Edition 20094371.

28 the DCFR Full Edition 20094295.

29 the DCFR Full Edition 20095222.

30 the DCFR Full Edition 20094295.

31 the DCFR Full Edition 20095222.

32 the DCFR Full Edition 20095218. 
Moreover, self-help is a physical, perhaps brutal, act that uses force to take back the goods in question. If so, why would VIII-6:202(3) need to allow self-help against indirect $\mathrm{OP}$ who by definition does not have the thing in hand? Here, we see that the indirect possessor should not always, if ever, be considered as possessors.

Third, the possession concept is again challenged in the stipulations of rei vindicatio. Pursuant to VIII-6:101(1), "[t] he owner is entitled to obtain or recover possession of the goods from any person exercising physical control over these goods..." The DCFR senses the need to allow owners to sue any person who exercises physical control, no matter if she is a PA or a direct possessor. Yet again, if possession is defined as physical control, VIII-6:101 could simply stipulate that the owner can sue the unentitled possessor. Interestingly, Comment I accompanying VIII-6:101notes that "[i]nstead of the words 'physical control' the word 'possession' could be used....The words are synonymous in this context."33 This implies that for the purpose of revindication, a PA is a possessor. My theory is only a step further-a PA is always a possessor.

Fourth, LRP is defined in an under-inclusive fashion. Under VIII-1:207(1)(b), a LRP has to follow the order of OP but can retain the goods until the OP pays the bill. If secretary S takes his boss B's dress to a dry cleaner and leave S's name as the contact person for convenience's sake, under the definition here, the dry cleaner is not a LRP because $\mathrm{S}$ is not an OP. In this bailment contract, whether $\mathrm{S}$ is an OP or not should not matter. But over-using the concept of OP shrinks the domain of LRP. In addition, according to VIII-1:207(2), a LRP can have indirect physical control over the goods. Thus, if $\mathrm{Y}$ rents a car from $\mathrm{Z}$ and $\mathrm{X}$ borrows or rents the car from $\mathrm{Y}, \mathrm{Y}$ is still a LRP, but what is the status of $\mathrm{X}$ ? $\mathrm{Z}$ is $\mathrm{OP}$ and $\mathrm{Y}$ is LRP, but $X$ does not have any "specific contractual relationship" with $Z$, so $X$ is not a LRP. Nonetheless, there seems to be no reason to exclude $X$ from the rank of LRP.

\section{My Solution: Possession as Physical Control (Period)}

My solution to this conceptual labyrinth is to simplify the concept of possession to physical/actual control and to end the use of cerebral concepts. ${ }^{34}$

\footnotetext{
33 the DCFR Full Edition 20095170.

${ }^{34}$ Chang (n 10) 123-124. Compare S Douglas, 'Is Possession Factual or Legal?' in E Descheemaeker (ed) The Consequences of Possession (Edinburgh University Press, Edinburgh 2014) 76 (calling possession a technical term, and its legal meaning can both narrow and expand the meaning of possession as physical control).
} 
As argued above, the word "physical" in the definition of possession causes interpretive problems. But we cannot simply remove this word, as using control alone to explain possession is not very helpful, either. My strenuous efforts in making sense of and understanding the possession concept in the DCFR run into a dead-end. The only feasible way is to discard the thousand-year-old practice of complicating possession. Brevity is the soul of wit. I give the examples of selfhelp and revindication above to show that possession as simply physical control is clear and simple. My critics may want to challenge me to solve legal issues where certain intentions to possess are necessary, to which I turn.

First, acquisition of ownership by continuous possession need not be changed substantively. ${ }^{35}$ VIII-4:101 and following articles recognize an OP's acquisition of ownership by continuous possession. ${ }^{36}$ It is widely agreed that the possessor shall have an intention to become an owner. ${ }^{37}$ Following my possession concept, VIII-4:101 will be essentially the same. The relevant article shall stipulate that the possessor, in addition to her physical control, has to possess with the belief of being the owner (good faith) or with the intention of becoming the owner (bad faith). In my book chapter, I discuss acquisition of ownership by continuous possession, first possession, ${ }^{38}$ etc. under the rubric of

\footnotetext{
35 For economic analysis of continuous possession (called "adverse possession" in the U.S.), see, for example, D Klerman, 'Jurisdiction, Choice of Law, and Property' in Y-c Chang (ed) Law and Economics of Possession (Cambridge University Press, Cambridge 2015); S Qiao, 'Small Property, Adverse Possession, and Optional Law' in Y-c Chang (ed) Law and Economics of Possession (Cambridge University Press, Cambridge 2015); RC Ellickson, 'Adverse Possession and Perpetuities Law: Two Dents in the Libertarian Model of Property Rights' (1986) 64 Washington University Law Quarterly 723; JM Netter, PL Hersch and WD Manson, 'An Economic Analysis of Adverse Possession Statutes' (1986) 6 International Review of Law and Economics 217; M Baker and others, 'Property Rights by Squatting: Land Ownership Risk and Adverse Possession Statutes' (2001) 77 Land Economics 360; J-Y Kim, 'Good-faith Error and Intentional Trespassing in Adverse Possession' (2004) 24 International Review of Law and Economics 1; B Depoorter, 'Adverse Possession' in B Bouckaert (ed) Property Law and Economics (Edward Elgar, Northampton, MA 2010); JE Stake, 'The Uneasy Case for Adverse Possession' (2001) 89 Georgetown Law Journal 2419; TJ Miceli and CF Sirmans, 'An Economic Theory of Adverse Possession' (1995) 15 International Review of Law and Economics 161; TW Merrill, 'Property Rules, Liability Rules, and Adverse Possession' (1984) 79 Northwestern University Law Review 1122; LA Fennell, 'Efficient Trespass: The Case for "Bad Faith" Adverse Possession' (2006) 100 Northwestern University Law Review 1037.

36 By the way, the DCFR Comment treats possessors who intend to be a LRP but do not have the right to possess as, confusingly, an OP. the DCFR Full Edition 2009 4355. This possessor may very well behave as if a LRP, not as if an OP. This problem would become more salient if the doctrine regarding acquisition of ownership by continuous possession will be applied to real property.

37 See also the DCFR Full Edition 20094292 (LRPs and PAs cannot acquire ownership by continuous possession). Note, however, that whether intention should be required for prescriptive acquisition is debatable, but it is not the focus of this article.

${ }^{38}$ For economic analysis of first possession, see A Bell, 'Title in the Shadow of Possession' in Y-c Chang (ed) Law and Economics of Possession (Cambridge University Press, Cambridge 2015); D Lueck, 'The Rule of First Possession and the Design of the Law' (1995) 38 Journal of Law \& Economics 393. See also the seminal contribution by CM Rose, 'Possession as the Origin of Property' (1985) 52 University of Chicago Law Review 73.
} 
"possession as a basis for acquiring ownership." 39 Only ownership acquisition 40 and relinquishment requires possessors to have certain animus.

The concept of possession, defined as the least common denominator, can easily be combined with other requirements (here, certain animus) in any doctrine. The downside of defining possession with intention built-in is that it needlessly interferes with the understanding of other doctrines. In good-faith purchase doctrines (VIII-3:101) and revindication doctrines, whether the possessors/purchasers and unlawful possessors intend to become owners is out of the question. Put differently, if in the political CFR, acquisition of ownership by continuous possession is not allowed, it would not be necessary to distinguish between OP and LRP.

Second, one might also challenge that my definition will greatly affect the protection of possession. Such an argument would go as follows: under my framework, PA is a possessor; direct possessor who uses PA to exercise physical control is highly unlikely (but depending on context) to be a possessor; and indirect possessor is surely not a possessor. More importantly, only possessors (PA and personal direct possessors) are entitled to recover possession, and indirect possessors and direct possessors who use PAs are no longer entitled to directly recover possession. ${ }^{41}$

My responses are that there is nothing wrong with a person originally with actual physical possession to recover possession from, say, a thief. PAs may not have incentives to file such a lawsuit, but direct possessors can 1) file revindication lawsuits if they are owners; 2) use the terms in the contract between direct possessors and PAs to request the latter to file a possession recovery lawsuits; or 3) subrogate PA in filing the lawsuit. ${ }^{42}$ Similar arguments apply to the context where there are an indirect possessor and a direct possessor and the latter does nothing in spite of the infringed possession. Indirect possessors, who under my framework cannot file for possession recovery, can

\footnotetext{
39 Chang (n 10) 113-117.

40 Possession serves important role in acquiring and maintaining ownership (or, title). See B Arruñada, 'The Titling Role of Possession' in Y-c Chang (ed) Law and Economics of Possession (Cambridge University Press, Cambridge 2015).

41 Comment A to VIII-1:205 (the DCFR Full Edition 2009 4292) states that because Chapter 6 of VIII does not protect PAs, so PAs are not possessors.

42 Subrogation is narrowly defined in the Annex of the DCFR as "in relation to rights, is the process by which a person who has made a payment or other performance to another person acquires by operation of law that person's rights against a third person.” My usage of subrogation is broader here, including legal actions such as creditors file lawsuits against their debtors' debtors in order to restore the solvency of the creditors' debtors. Article 1166 of the French Civil Code and Articles 242 of the Taiwan Civil Code, for example, allow such a subrogation.
} 
also 1) file for revindication if they are owners; 2) request direct possessors to sue; or 3) subrogate direct possessors to sue.

Granted, revindication lawsuits may not always be easy. the DCFR Comment notes that "[I]n some legal systems, the requirement for the proof of ownership...are quite strict (probatio diabolica), in others they are not (e.g. France)." 43 In an ideal world, France would be a role model, so that (in)direct possessors who are owners can with reasonable evidence prove their ownership and file for revindication. Yet even in European jurisdictions where proof of evidence is a problem - and this is treated as given-establishing a broader subrogation right in the DCFR, at least in the context of protecting possession and ownership, should be warranted. Subrogation and a simple concept of possession are two building blocks in the private law system, and their combination shall be both effective in protecting possession and ownership and easily understandable-a possession concept that both professionals and laymen can understand in everyday life ${ }^{44}$ enable laymen to obey the law and make the life of legal professionals easier in enacting, applying, and understanding law.

\section{Is Possession a Fact or a Right?}

Comment E accompanying VIII-6:101 ponders whether possession is a right, a proprietary right or a mere fact. ${ }^{45}$ In my book chapter, ${ }^{46}$ I contend that possession is both a fact and a subsidiary right. ${ }^{47}$ Possession is a fact when the physical control aspect is under discussion. Possession as a subsidiary right, called possessory rights in my edited book, ${ }^{48}$ correspond (roughly) to the "right to possess" that appears multiple times in the articles and Comments of the DCFR. Yet this right to possess is not clearly defined and is therefore clarified below.

The right to possess is one of the incidents in ownership. VIII. - 1:202 defines ownership as "the most comprehensive right a person, the 'owner', can

\footnotetext{
43 the DCFR Full Edition 2009 5167. See also Chang (n 10) 111.

44 See generally TW Merrill, 'Ownership and Possession' in Y-c Chang (ed) Law and Economics of Possession (Cambridge University Press, Cambridge 2015).

45 the DCFR Full Edition 2009 5164-5166.

46 Chang (n 10) 109-110.

47 Admittedly, although possession as a fact, meaning physical control, is directly related to the discussion on the economy of concept, possession as a right (or not) is not an issue that warrants the same analysis. Nevertheless, one cannot fully understand the concept of possession is these two dimensions are not distinguished.

48 See for instance ibid; DB Kelly, 'Dividing Possessory Rights' in Y-c Chang (ed) Law and Economics of Possession (Cambridge University Press, Cambridge 2015).
} 
have over property, including the exclusive right, so far as consistent with applicable laws or rights granted by the owner, to use, enjoy, modify, destroy, dispose of and recover the property." This can be considered as consistent with my claim that ownership is a bundle of subsidiary rights. ${ }^{49}$ That is, ownership contains multiple subsidiary rights which could be conceptualized in different fashions. Some may identify the right to possess as one of the incidents, whereas it appears that the DCFR has chosen to subsume the right to possess under other incidents, such as the subsidiary right to use. No matter how the bundle is described, the numerus clausus principle limits the way an owner can divide and re-package the subsidiary rights. Certain limited property rights contain the right to possess, such as usufruct, while others do not, such as mortgage. ${ }^{50} \mathrm{My}$ ownership theory further suggests that the right to possess can be divided into in rem and in personam right to possess. The right to possess derived from a limited property right is in rem. The right to possess derived from contract such as lease is in personam.

Without explicitly spelling out the nature of the right to possess, the DCFR contains several problematic articles and Comments. First, VIII-6:301(2) (entitlement to recover in case of better possession) stipulates that "[ $t$ ]he former possession is "better" than the current possession if the former possessor is in good faith and has a right to possess, while the other person has no right to possess, the goods...." That is, to be eligible for possession recovery, the former possessor has to be both "in good faith" and "[having] a right to possess." Good faith/bad faith should only matter when the possessor does not have a right to possess. What does it mean to be bad faith about one's having a right to possess? Comment $\mathrm{E}$ to this article states that good faith is a reasonable belief that one has a right to possess. ${ }^{51}$ But since "having a right to possess" is already required, the good faith requirement is not only redundant but also perplexing. As long as the former possessor has in rem or in personam right to possess, while the current possessor has neither, the former should be entitled to recover from the latter, regardless of good faith or bad faith.

Second, the DCFR Comment contends that in a double sale, the later purchaser who does not gain physical control only "has the right to possess" 52 -

\footnotetext{
49 Chang (n 10) 109-10.

${ }^{50}$ It should be noted that my view of ownership is more consistent with the subtraction method rather than the limitation method of conceptualizing ownership. See Akkermans (n 18) for comparison of the two. Akkermans also points out that the DCFR recognizes Anwartschaftsrecht as a limited proprietary right, which is inconsistent with the subtraction method of defining ownership.

51 the DCFR Full Edition 20095280.

52 the DCFR Full Edition 20094357 (Illustration 8).
} 
here, the right to possess is in personam, as it is only exerted against the seller, not the other purchaser who has gained title. The Comment should have been clearer on this.

Third, the DCFR Comment considers it "unproblematic" to treat the right of a lessee to possess (where lease is a contract) as a proprietary right. ${ }^{53} \mathrm{I}$ respectfully disagree. A limited property right that contains a right to possess would have in rem effect (that is, automatically against the whole world ${ }^{54}$ ). A lessee, however, does not have an in rem right to possess. A lease contract gives the lessee an in personam right to possess against the lessor. Chapter 6 of Volume VIII of the DCFR awards a mere possessor a wide right to recover possession. ${ }^{55}$ Still, as made clear by Comment D to VIII-6: 203,56 the former possessor (such as a lessee of a car) cannot recover possession against a current possessor who did not unlawfully dispossess. Therefore, unlike an owner or a holder of a limited property right, who can recover possession against anyone currently exercising physical control, a lessee's right to possess is still not unlimited, not against the whole world. As a result, it would be problematic to treat the right to possess as in rem (or, for that matter, proprietary).

Finally, in the DCFR, one can even encounter right to possess where the source of the right is unclear. ${ }^{57}$ According to VIII-1:207(1)(a), a LRP has to acquire her right to possess the goods from her contract with OP. Nevertheless, an OP is not necessarily an owner; rather, an OP could be a person who tries to acquire ownership through continuous possession (or, prescriptive acquisition). How could such an OP, who possesses without any right, gives the LRP "the right to possess" the goods, no matter an in rem one or an in personam one? For the purpose of defining LRP, whether OP is the owner or not does not matter. What is important for the definition of LRP is that a person holds the goods but regards another person as the owner. For lack of attention to the notion of right to

\footnotetext{
53 the DCFR Full Edition 20095166.

54 Y-c Chang and HE Smith, 'An Economic Analysis of Civil versus Common Law Property' (2012) 88 Notre Dame Law Review 1, 33.

55 The recovery right under the DCFR is in many ways wider than that under domestic laws in EU jurisdictions, as the (former) possessor needs not possess the thing in question for more than one year, and the dispossession does not have to be violent under the DCFR. Chang (n 10) 110.

56 the DCFR Full Edition 20095238 (Illustration 2).

57 It is worth noting one place where I think the DCFR makes an ingenious design. I have argued that unlawful possessors should not be able to recover their possession through the court. Chang (n 10) 112-113. the DCFR still allows unlawful possessors to bring such a claim to court, but the other party can counter claim her better possession, the court should take that into account pursuant to VIII-6:204. I shall emphasize that under my theory better possession has to mean that the other party has either in rem or in personam right to possess to prevail. VIII-6:301(2) stipulates that when neither parties has a right to possess, and both of them are in good faith, the current possession prevails. I agree. I would extend this current-possession-prevail position to bad-faith parties not entitled to possess.
} 
possess, the DCFR inadvertently leaves a gap in LRP.

\section{CONCLUSION}

To properly construct the concept of possession, one has to keep an eye on the basic building blocks of property law, even the whole private law. While my view of property law, such as property as a structured bundle of relations and ownership as a bundle of subsidiary rights, may be unconventional, it is in no way the precondition for my proposed simplified definition of possession. Possession as simply physical control can be inserted in any civil code, and only minor adjustments are needed to maintain the substantive contents of other private law doctrines. When drafters of, say, a European Civil Code, start with possession as physical control and stick with this simple concept throughout the civil code, they shall find that private law will become easier to construct and easier for laymen and professionals alike to comprehend.

While the drafters of the DCFR drifted away from the common core approach, they started with it. One demerit of the common core approach is to perpetuate path dependency. Germany, France, the Netherlands, and many other countries contain overly complicated concept of possession. The common core approach, either choosing a majority conceptual system or extracting the least common denominator, is unlikely to run away from the traction of the undesirable status quo of complication. Drafters who employ the best solution approach have to step back and, preferably, start from scratch in order to design the truly most efficient mechanism. This article provides one way of conceptualizing possession, and Law and Economics of Possession has more to offer. 


\section{$\underline{\text { References }}$}

Y-c Chang (ed), Law and Economics of Possession (Cambridge University Press, Cambridge 2015)

Y-c Chang, 'Property Law with Chinese Characteristics: An Economic and Comparative Analysis'

(2012) 1 Brigham-Kanner Property Rights Conference Journal 345

Y-c Chang, 'Access to Landlocked Land: A Case for a Hybrid of Property and Liability Rules' (2013) working paper

Y-c Chang, 'An Economic and Comparative Analysis of Specificatio (the Accession Doctrine)' (2014)

39 European Journal of Law and Economics 225

Y-c Chang and LA Fennell, 'Partition and Revelation' (2014) 81 The University of Chicago Law

Review 27

U Mattei, Basic Principles of Property Law: A Comparative Legal and Economic Introduction

(Greenwood Press, Westport, Conn. 2000)

H Hansmann and U Mattei, 'The Function of Trust Law: A Comparative Legal and Economic Analysis' (1998) 73 New York University Law Review 434

AF Salomons, 'On the Economics of Good Faith Acquisition Protection in the DCFR' in A Somma (ed)

The Politics of the Draft Common Frame of Reference (Wolters Kluwer, New York, NY 2009)

RA Epstein, 'Possession and Licenses: the FCC, Weak Spectrum Rights, and the LightSquared Debacle' in Y-c Chang (ed) Law and Economics of Possession (Cambridge University Press, Cambridge 2015)

E Descheemaeker, 'The Consequences of Possession' in E Descheemaeker (ed) The Consequences of Possession (Edinburgh University Press, Edinburgh 2014)

AF Salomons, 'The Purpose and Coherence of the Rules on Good Faith Acquisition and Acquisitive Prescription in the Draft Common Frame of Reference: A Tale of Two Gatekeepers' (2013) 21

European Review of Private Law 843

HE Smith, 'On the Economy of Concepts in Property' (2012) 160 University of Pennsylvania Law Review 2097

RA Epstein, 'Possession as the Root of Title' (1979) 13 Georgia Law Review 1221

HE Smith, 'The Elements of Possession' in Y-c Chang (ed) Law and Economics of Possession (Cambridge University Press, Cambridge 2015)

CM Rose, 'The Law Is Nine-tenths of Possession: An Adage Turned on Its Head' in Y-c Chang (ed) Law and Economics of Possession (Cambridge University Press, Cambridge 2015)

D Lewinsohn-Zamir, 'What Behavioral Studies Can Teach Jurists about Possession and Vice Versa' in Y-c Chang (ed) Law and Economics of Possession (Cambridge University Press, Cambridge 2015) Y-c Chang, 'The Economy of Concept and Possession' in Y-c Chang (ed) Law and Economics of Possession (Cambridge University Press, Cambridge 2015)

TW Merrill, 'Possession as a Natural Right' (2015) 9 New York University Journal of Law \& Liberty 345

B Akkermans, 'The role of the (D) CFR in the making of European property law' in V Sagaert, M 
Yun-chien Chang

Storme and E Terryn (eds), The Draft Common Frame of Reference (DCFR): A National and

Comparative Perspective (Intersentia, Cambridge 2012)

JE Krier and C Serkin, 'The Possession Heuristic' in Y-c Chang (ed) Law and Economics of Possession

(Cambridge University Press, Cambridge 2015)

D Kahneman, Thinking, Fast and Slow (Farrar, Straus and Giroux, New York, NY 2011)

S Douglas, 'Is Possession Factual or Legal?' in E Descheemaeker (ed) The Consequences of Possession

(Edinburgh University Press, Edinburgh 2014)

D Klerman, 'Jurisdiction, Choice of Law, and Property' in Y-c Chang (ed) Law and Economics of

Possession (Cambridge University Press, Cambridge 2015)

S Qiao, 'Small Property, Adverse Possession, and Optional Law' in Y-c Chang (ed) Law and Economics of Possession (Cambridge University Press, Cambridge 2015)

RC Ellickson, 'Adverse Possession and Perpetuities Law: Two Dents in the Libertarian Model of Property Rights' (1986) 64 Washington University Law Quarterly 723

JM Netter, PL Hersch and WD Manson, 'An Economic Analysis of Adverse Possession Statutes' (1986)

6 International Review of Law and Economics 217

M Baker and others, 'Property Rights by Squatting: Land Ownership Risk and Adverse Possession Statutes' (2001) 77 Land Economics 360

J-Y Kim, 'Good-faith Error and Intentional Trespassing in Adverse Possession' (2004) 24 International Review of Law and Economics 1

B Depoorter, 'Adverse Possession' in B Bouckaert (ed) Property Law and Economics (Edward Elgar, Northampton, MA 2010)

JE Stake, 'The Uneasy Case for Adverse Possession' (2001) 89 Georgetown Law Journal 2419

TJ Miceli and CF Sirmans, 'An Economic Theory of Adverse Possession' (1995) 15 International

Review of Law and Economics 161

TW Merrill, 'Property Rules, Liability Rules, and Adverse Possession' (1984) 79 Northwestern

University Law Review 1122

LA Fennell, 'Efficient Trespass: The Case for "Bad Faith" Adverse Possession' (2006) 100

Northwestern University Law Review 1037

A Bell, 'Title in the Shadow of Possession' in Y-c Chang (ed) Law and Economics of Possession

(Cambridge University Press, Cambridge 2015)

D Lueck, 'The Rule of First Possession and the Design of the Law' (1995) 38 Journal of Law \&

Economics 393

CM Rose, 'Possession as the Origin of Property' (1985) 52 University of Chicago Law Review 73

B Arruñada, 'The Titling Role of Possession' in Y-c Chang (ed) Law and Economics of Possession

(Cambridge University Press, Cambridge 2015)

TW Merrill, 'Ownership and Possession' in Y-c Chang (ed) Law and Economics of Possession

(Cambridge University Press, Cambridge 2015)

DB Kelly, 'Dividing Possessory Rights' in Y-c Chang (ed) Law and Economics of Possession 
Yun-chien Chang

(Cambridge University Press, Cambridge 2015)

Y-c Chang and HE Smith, 'An Economic Analysis of Civil versus Common Law Property' (2012) 88 Notre Dame Law Review 1 